\title{
.
}

\section{THE OCEAN'S STORAGE SYSTEM: HOW PLANKTON inflUENCES Climate CHANGE}

THE OCEAN HAS AN INCREDIBLE CAPACITY TO STORE CARBON. IT HAS BEEN ABSORBING ONE THIRD OF HUMANITY'S EMISSIONS OVER THE LAST CENTURY OR TWO, AND ULTIMATELY WILL ABSORB MUCH OF OUR FUTURE EMISSIONS. PHYTOPLANKTON COMMUNITIES PLAY A KEY ROLE IN THE OCEAN CARBON CYCLE, AS CARBON IS REMOVED FROM THE ATMOSPHERE AND TRANSFERRED TO THE DEEP OCEAN FOR LONG-TERM STORAGE. PROFESSOR KATSUMI MATSUMOTO OF THE UNIVERSITY OF MINNESOTA IN THE US USES COMPUTER MODELS TO UNDERSTAND THIS PROCESS, AND WHAT IT MEANS FOR GLOBAL CLIMATE CHANGE

\section{TALK LIKE AN OCEAN} BIOGEOGHEMIST

BIOLOGICAL PUMP - the ocean's

biologically driven capture and sequestration of carbon from the atmosphere

\section{CARBON CYCLE - the group of}

processes that involve converting carbon compounds from one form to another, such as photosynthesis, respiration, decay, and combustion

CARBON SEQUESTRATION - the process of capturing and storing atmospheric carbon dioxide

PHOTOSYNTHESIS - the chemical process by which plants convert carbon dioxide, water and light into organic molecules

PHYTOPLANKTON - microscopic marine plants that inhabit the ocean's surface waters TAXONOMY - the system of classifying organisms
While humanity is busy pumping carbon into the atmosphere, the ocean is busy absorbing it. Carbon dioxide is soluble in seawater, and from here it can enter living organisms. Phytoplankton - microscopic marine plants live near the ocean's surface and incorporate carbon into their cells via photosynthesis. Through death or other food chain processes, some of this carbon ultimately sinks into the deep ocean where it is stored in seawater and ocean floor sediments. In this way, the ocean acts as a vitally important carbon store, significantly slowing the rate of climate change.

This effect is known as the 'biological pump'. "The biological pump is the vertical transfer of photosynthesis-derived organic matter from the surface ocean to the deep ocean," says Professor Katsumi Matsumoto of the University of Minnesota. "This means that carbon dioxide from the atmosphere is moved to deep waters where it can be sequestered for centuries or more. The stronger the biological pump, the more it cools the global climate through lower atmospheric carbon dioxide."

However, the rate at which this happens is partly determined by the phytoplankton communities involved. Depending on environmental conditions, these phytoplankton communities can vary considerably, which affects their role in the global ocean carbon cycle. Katsumi works in the field of ocean biogeochemistry and uses computer models to predict the growth of these microscopic organisms and their influence on the carbon cycle at the global scale.

\section{PHYTOPLANKTON}

"All life forms grow using the same basic elemental ingredients, which include carbon $(\mathrm{C})$, nitrogen $(\mathrm{N})$ and phosphorous $(\mathrm{P})$," says Katsumi. "Carbon is the basic building block of cells, nitrogen is a major component of proteins, and phosphorous is essential for nucleic acids such as DNA." Katsumi studies the $\mathrm{C}: \mathrm{N}: \mathrm{P}$ ratio of phytoplankton - in other words, how and why the proportions of these three elements vary within these organisms.

This work involves challenging a historical precedent. "Almost a century ago, Alfred Redfield observed that the $\mathrm{C}: \mathrm{N}: \mathrm{P}$ ratio in marine plankton was stable and very similar to the $\mathrm{C}: \mathrm{N}: \mathrm{P}$ ratio of seawater. This observation became known as the 'Redfield ratio' and is a central idea in biological and chemical oceanography," says Katsumi. "However, 



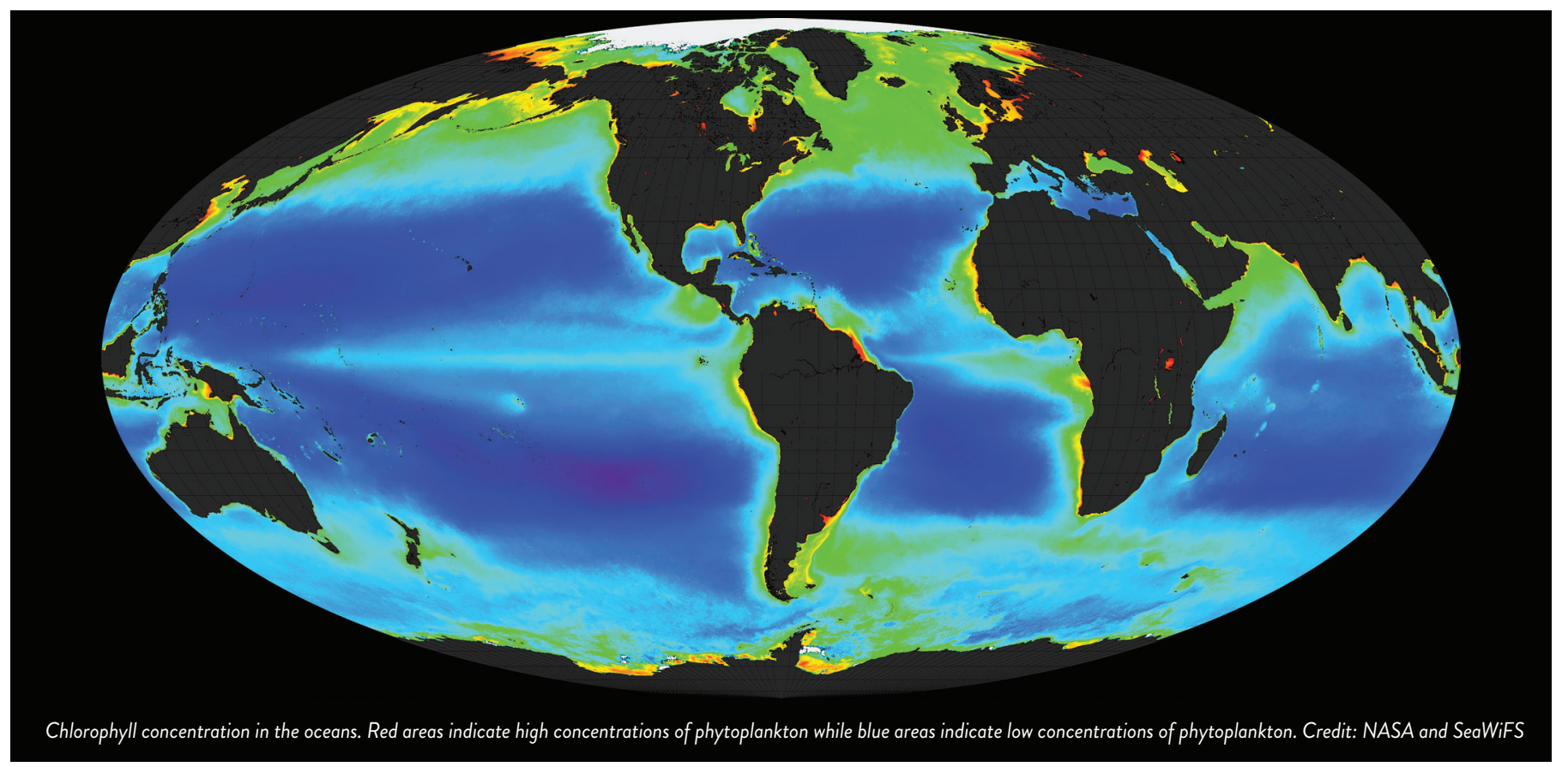

\section{HOW DID KATSUMI BECOME
AN OCEAN BIOGEOCHEMIST?}

WHAT WERE YOUR INTERESTS AS A CHILD?

I have always been interested in nature. As a young boy, I enjoyed hiking with my family and catching insects with my brothers. As a teenager, I was concerned about environmental protection and conservation.

\section{WHO INSPIRED YOU TO BECOME A} SCIENTIST?

None of my family were scientists while I was growing up, so it was not on my radar. Then, my older brother pursued an advanced degree, which opened my eyes to further education. Later, I was inspired by the deep knowledge of my geoscience professors such as Tom Webb at Brown University and Wally Broecker at Columbia University.

WHAT PERSONAL ATTRIBUTES HAVE MADE YOU A SUCCESSFUL SCIENTIST? Perseverance is essential. "Genius is 1 percent inspiration and 99 percent perspiration," as Thomas Edison said, and perseverance has probably been the most important reason for any successes I have had. Luck is often involved too, but you need persistence to get lucky.

HOW DO YOU OVERCOME

OBSTACLES IN YOUR WORK?

Again, through perseverance. I dedicate as much time and effort as I can to a problem,

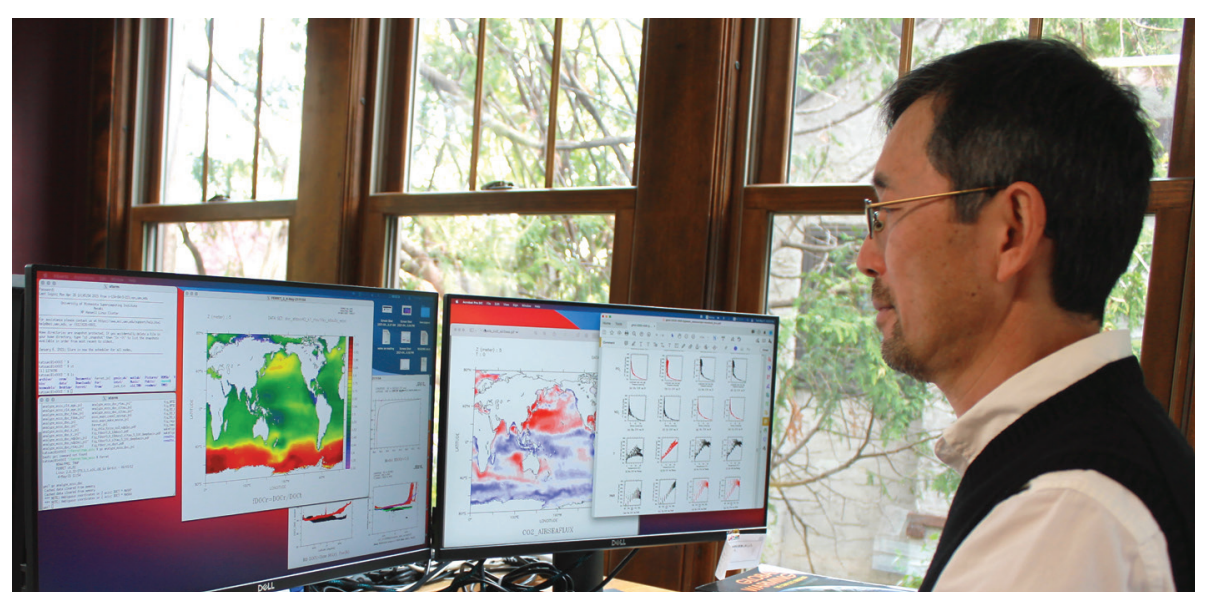

often while learning from others around me. I stop if I feel I have pushed as hard as possible, then come back to the problem after a while. I am often able to overcome obstacles after going through this process a few times, though it may take a while!

WHAT ARE YOUR PROUDEST CAREER ACHIEVEMENTS SO FAR?

I am most proud of the publications led by my students. I also am proud of the opportunities I get as a visiting professor. During past sabbaticals, I have carried out research in Sydney, Hobart, Tokyo and Oxford.

Professor Katsumi Matsumoto remotely logs into supercomputing facilities to model global ocean biogeochemistry. 